\title{
Student Career Management - Private and Public Sector Involvement
}

\author{
Alina-Mihaela FAGATEANU \\ Lucian Blaga University of Sibiu, Sibiu, Romania \\ alina.fagateanu@gmail.com \\ Sergiu Ștefan NICOLAESCU \\ Lucian Blaga University of Sibiu, Sibiu, Romania \\ sergiu.nicolaescu@ulbsibiu.ro \\ Claudiu Vasile KIFOR \\ Lucian Blaga University of Sibiu, Sibiu, Romania \\ claudiu.kifor@ulbsibiu.ro \\ Silvia MĂRGINEAN \\ Lucian Blaga University of Sibiu, Sibiu, Romania \\ silvia.marginean@ulbsibiu.ro
}

\begin{abstract}
The need of high level prepared students into the private sector is continuously increasing because of the raised innovation level requested by market. In this case study, experts were involved from the private sector in collaboration with the academic sector for a career management project initiated for students; the monitored KPIs had a positive trend. The purpose of the paper is to analyze and show the results of a project with big impact on the education of students from Romania and on the collaboration between the private and public sector. A model of career management is proposed, in which the knowledge is mobilized into a spiral of education levels with influence from the public sector, the private sector and the government. The positive influence of private sector it is highlighted and it is advised to introduce the management of career into student's education.
\end{abstract}

Keywords: education, career management, private sector, private-public collaboration, knowledge mobilization.

\section{INTRODUCTION}

Work has always been an inseparable part of human activity and working careers can be understood in many ways (Vuori et al. 2015). Private sector and academic sector are in an institutional conflict based on the reason that the theoretical aspects are not possible to be transposed into practice (Sauermann et al. 2013) The career literature has many researches which can be found inside, but also outside of the career management system found in 
organizations (De Vos et al. 2013). Gangl argued many young workers have difficulties entering a sustainable working career, as they attempt to build their personal lives and work life identities (Gangl, 2002).

Today's unpredictable employment environment and frequent transformations in work organizations cause uncertainty, anxiety, stress and symptoms of depression (Ferrie et. al. 2005). For example in Europe, depression has become the major reason for work disability pensions (Ahola et. al. 2009). Any experience in the organizations brings a positive attitude on the students in their employment process in the private sector or entrepreneurship (Fritsch et. al.2012). Structured work experience has clear, positive effects on the ability of graduates to secure employment in "graduate level" jobs within six months of graduation (Taylor et. al. 2014). The older organizations have their strong point in the human resources, but they also increasingly use more traditional methods of career management (e.g. strategy, training, integration, paternalism) and the new trends in the organizations should focus on the talent management (Farndale et. al. 2010).

It was found that are four crucial dimensions to successful career support for new academics: managing expectations, career management, mentoring and professional development (Adcroft et. al. 2013). The reason of this study regards the need of bringing up on the labor market for students from different domains to an increased percent of hiring. One of the challenges of linking results of academic research to industry is the tacit nature of knowledge (Pavitt, K., 1998). The transition of academic researchers to private sector employment is increasingly (Link et. al. 2007); this gives a motivation of exploring the partnership of public and academic sector into improving the education of student's career management.

Students of the superior level (master/PhD) are easily integrated on the private sector (industry/entrepreneurship) if their individual's career mobility depends on their research field (Martinelli, 2001).

The impact of research is on both on private and academic sector, the private sector needs prepared employees and academic sector has as main objective the employment of students. The literature is focusing on what a person should do for the management of career. This paper is focusing on how the stakeholders are influencing the career of a student and how this can be enhanced; the stakeholders are the public sector, the private sector and the govenment.

Today, the trend of society is focus to creation of knowledge. On the one hand, new forms of knowledge production are emerging, and on the other, both science and society are experiencing a rapid acceleration in new forms of knowledge utilization (Estabrooks et. al. 2008). In this fight for bringing more students in the workplaces, the key is Knowledge Mobilization which has influences from private sector, academic sector and government. 


\section{KNOWLEDGE MOBILIZATION}

The knowledge mobilization is the process that links the academic research (social science and humanities and other knowledge) with the non-academic decision makers, in such away this researches brings decisions about public strategy and professional practice. Based on that, the social innovation is the results of this process (Phipps et. al. 2012).

The knowledge mobilization has various terms, among organizations, which has a small difference in meaning, such as: knowledge transfer, knowledge translation, knowledge exchange, knowledge transfer \& exchange, knowledge translation and transfer, knowledge mobilization, and knowledge integration.

Knowledge Mobilization "is the open process of putting available knowledge into active service to benefit not just one particular corporate or organizational structure, but for the greater benefit of all in society" (Phipps et. al. 2012).

The focus of the private - academic sectors partnership is on the methods of mobilizing knowledge to create innovation. In 2008, Beth Levin create a tripartite frame and one of this questions is applicable to the study case from this paper because is based on finding the process which make available the knowledge to all involved students. Another applicable question is about how create an easily interaction and feedback between the students and influential sectors (Klenk et. al. 2015).

\section{CASE STUDY}

This paper is presenting and analyzing a project that has as main objective the education of students regarding management of career.

The case study is applied to education from Romania, the project has as main objective the integration of students on the labor market in relevant professional fields of the studied specialization; this was done by developing students work skills as a result of participation into a counseling and guidance integrative program.

Some prestigious universities from Romania are involved into the project; the partners are listed into table 1.

Table 1. Main project Partners

\begin{tabular}{|l|l|}
\hline Type & Name \\
\hline Solicitant & West University of Timisoara (UVT) \\
\hline Partner 1 & SC Gi Group Staffing Company SRL \\
\hline Partner 2 & „Lucian Blaga” University of Sibiu (ULBS) \\
\hline Partner 3 & University from Oradea \\
\hline Partner 4 & University from Bucharest \\
\hline Partner 5 & Academy of Economic Studies from Bucharest \\
\hline Partner 6 & „Alexandru Ioan Cuza” University of Iași \\
\hline Partner 7 & „Constantin Brâncuși” University of Târgu-Jiu \\
\hline
\end{tabular}


The paper will focus on the Lucian Blaga University involvement into the counseling and guidance of students, together with the partners from private sector. The project took place under the name: “Today's students, tomorrow's professionals". This project aims to increase access to labor market opportunities for 800 students, from the target group of $1,650,000$ persons.

Students involved into the project came from different specialization fields, the biggest percentage came from Engineering sector, being followed closely by the Business and Economics sector. The distribution of students on different domains is exposed in figure 1 .

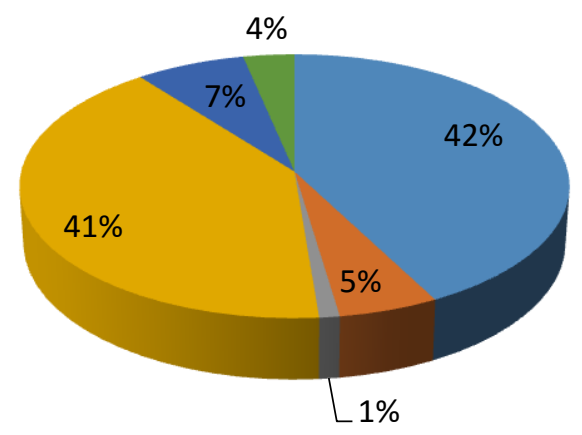

The Faculty of Engineering

The Faculty of Letters and Arts

The Faculty of Sciences

Faculty of Economic Sciences

- Faculty of Social and Human Sciences

- The Faculty of Theology

\section{Figure 1. Distribution of students in Faculties}

The indicators of project are:

$>800$ beneficiaries students career counseling services;

$>16$ Career Management Conferences;

$>35$ companies study visit;

> 15 partnerships with employers, to share experience and best practices;

During the project the students had the opportunity to visit the companies and discuss with employees of the company, to gain some knowledge on the companies and the work itself.

Private sector has a major contribution on the knowledge mobilization in this project through the company visits, organizations speaches etc. The number of students that experienced a study company visit is presented in figure 2 . 


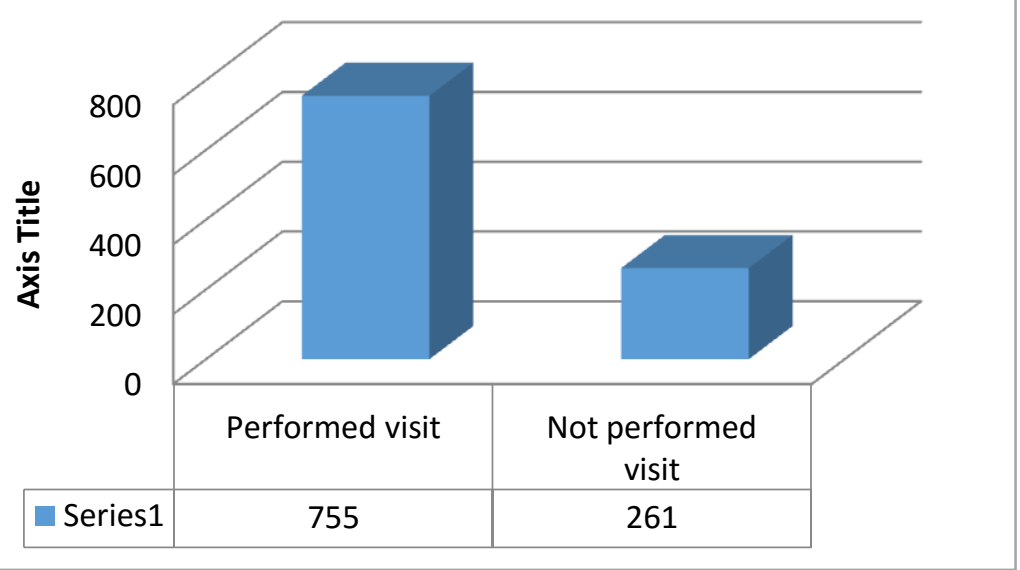

Figure 2. Company visit

Project components are detailed into table below:

Table 2. Project Stucture

\begin{tabular}{|c|c|c|}
\hline No. & $\begin{array}{l}\text { Component of } \\
\text { the project }\end{array}$ & Short describe \\
\hline 1 & $\begin{array}{l}\text { Career } \\
\text { management } \\
\text { conference }\end{array}$ & $\begin{array}{l}\text { - Documents are signed and informational } \\
\text { materials related to the project are received; } \\
\text { - Participation in a chat session related careers } \\
\text { and labor market, with speakers selected from } \\
\text { the private sector; } \\
\text { - Receiving informational materials on the } \\
\text { preparation CV, a letter cover and how can go } \\
\text { to a job interview; }\end{array}$ \\
\hline 2 & $\begin{array}{lr}\text { Evaluation } & \text { of } \\
\text { generic } & \text { skills } \\
\text { (General Counsel) }\end{array}$ & $\begin{array}{l}\text { - Participation in a computerized testing, } 1 \text { to } 1 \text {, } \\
\text { under the supervision and guidance of a } \\
\text { professional } \\
\text { - Getting results and making requests of } \\
\text { personalized interpretations or advice. }\end{array}$ \\
\hline 3 & $\begin{array}{l}\text { Companies study } \\
\text { visit }\end{array}$ & $\begin{array}{l}\text { - Visit a number of employers relevant to your } \\
\text { area of specialization to gain more practical } \\
\text { knowledge on the organization and functioning } \\
\text { of economic entities. }\end{array}$ \\
\hline
\end{tabular}




\begin{tabular}{|l|l|}
\hline $\begin{array}{l}\text { Specific } \\
\text { assessment of } \\
\text { skills and building } \\
\text { professional } \\
\text { development plan } \\
\text { (specific } \\
\text { counseling) }\end{array}$ & $\begin{array}{l}\text { - Go through an application process and } \\
\text { selection criteria to qualify for this activity; } \\
\text { - Participating in a thorough evaluation, both }\end{array}$ \\
$\begin{array}{l}\text { interpretations and interventions; } \\
\text { Conferences on } \\
\text { horizontal } \\
\text { objectives }\end{array}$ & $\begin{array}{l}\text { - Attractive and actual topics: sustainable } \\
\text { development; Innovation and information and } \\
\text { communications technology. }\end{array}$ \\
\hline $\mathbf{5}$ & \\
\hline
\end{tabular}

The targets of the "Lucian Blaga" University project were reached, until this stage 815 students received career counseling services, 20 Career Management conferences were conducted and 36 visits to companies were organized. The number of private companies involved into project was bigger then the one planned, between them being counted: Continental Automotive Systems Sibiu, Ropardo Sibiu Business Center, Hirschmann Târgu Mureș, REEA Târgu Mureș, Danubius Sovata, Greiner Sibiu, CEC Bank, Gedeon Richter Târgu Mureș, Marquart Sibiu, Boromir, Al-Ko, Keep Calling, Visma, Am Ring.

\section{PROPOSED CARRER PATH MODEL}

Carrer Path model is designed for the education of students regarding their way into the work stage. Students carrer management awareness needs to be exposed, the carrer being one of the most important objectives of education. A mandatory factors in a good career is the know-how owned by the person in that field of work.

In this fight for bringing more students in the workplaces, the key is Knowledge Mobilization which has influences from private sector, academic sector and government. The government has a financial involvement because the project was started with cofinanced from the European Social Fund Operational Programme "Human Resources Development".

The influencing sectors: private-academic-government, have an impact in the growth and development on career for each person. To satisfy the requirements from private sector is necessary the government support to the academic sector. The influence depending on the amount of knowledge transferred. 


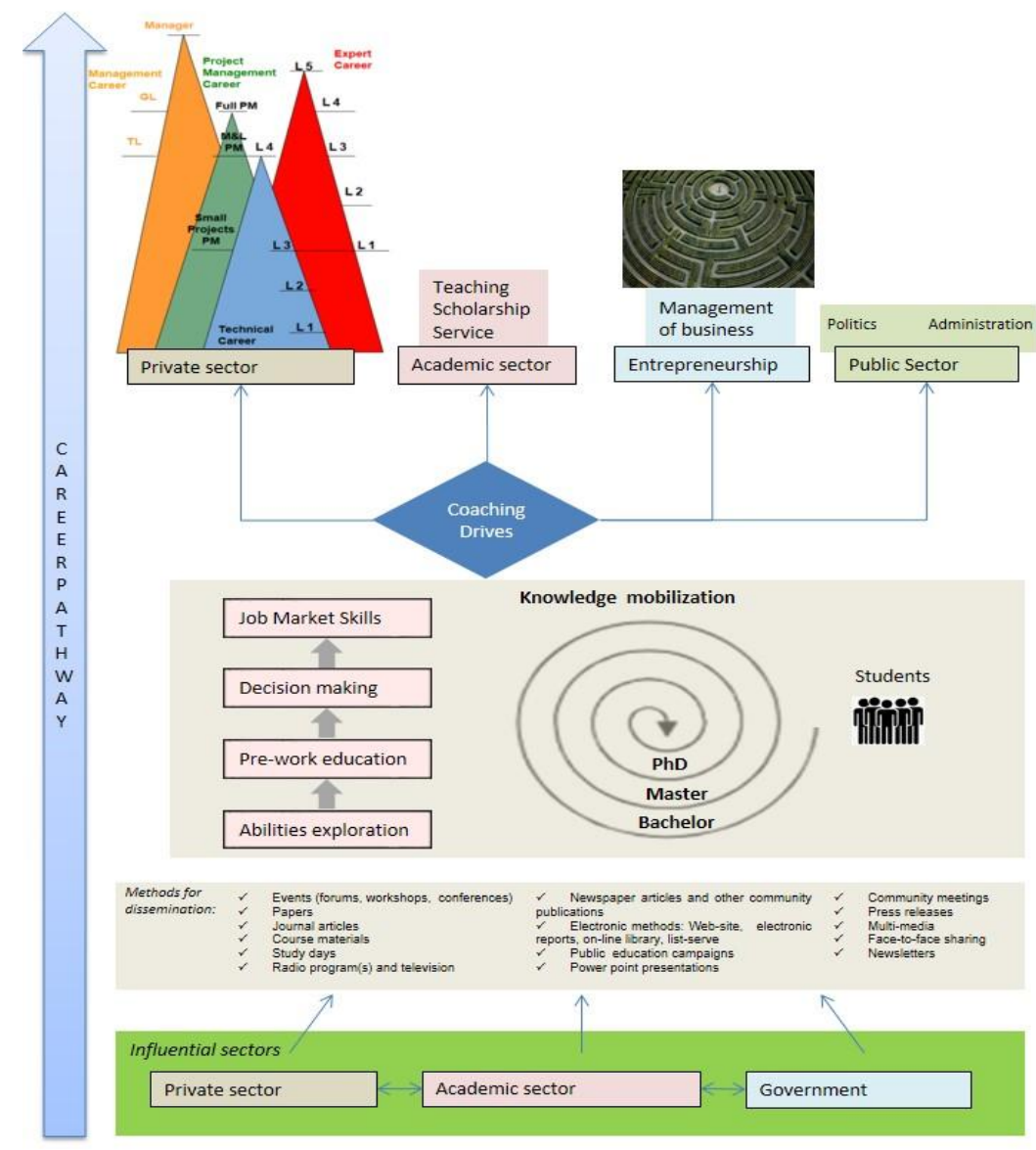

Figure 3. Creation of the Career PathWay

The project used formal and informal knowledge mobilization plans. The dissemination methods are: events (forums, workshops, conferences); papers; journal articles; course materials; study days; newspaper articles and other community publications; radio program(s) and television; public education campaigns; community meetings; press releases; multi-media; electronic methods: Web-site, electronic reports, on-line library, listserve; face-to-face sharing; newsletters; power point presentations.

The knowledge mobilization is starting with general knowledge in a wide domain through the bachelor education phase. In will continue with enhance of specific knowledge in a narrow domain during the master program and will reach the final stage of education with the $\mathrm{PhD}$ phase, in which the specific knowledge in a chosen narrow sector is assimilated. The students of the superior level (master / PhD) are easily integrated on the private sector 
(industry / entrepreneurship) if their professional expertise is in the same filed as the research.

There are four phases that must be followed in order to enhance the chance of a good career:

$\rightarrow$ Personal exploration includes skills, personality, interests, values. In first phase before creation of the career pathway it's mandatory to perform a self discover.

$\rightarrow$ Pre-work education is divided into research and experimental education.

Research side: Job market trends, employers, work environment, informational interview. This step is necessary to create a picture of what happens outside and what others do.

Experimental side: Internships, volunteering, part time jobs, and company study visits.

$\rightarrow$ Decision making processes involve the accumulated knowledge, the abilities and the intuition drives their future. In this project, all students have support on their decision regarding their career choices through the coaching sessions. In these sessions they can ask the industry experts, they make plans and they try to understand the risks of the decisions that they will make.

$\rightarrow$ Job search Market Skills: networking, resume, cover letter, interviews, negotiations, research on job field and research on company background. The last step is needed in order to outline the career pathway, being necessary to know how to sell the skills and the acquired knowledge.

\section{CONCLUSION AND FURTHER APPLICABLE WORK}

The original contribution on this paper is the model of career pathway consists into knowledge mobilization for students in order to get the desired and right job for them; the model was validated in a project for Romanian students. It was highlighted the importance of the concerned sectors (public - private - government sectors) and the high effectiveness of carrying out the career management project for students.

In this moment "Lucian Blaga" University is in the KPI targets, was reached 815 counseled students, 20 conferences (target was 16 conferences), company visits is ongoing, in this moment the status is 36 visits, but are scheduled for autumn 2015 approximately 5 visits.

It is considered that the student career management reaches a new revolutionary phase, a phase in which the students are guided and advised by the private sector experts.

\section{REFERENCES}

Vuori, J., \& Toppinen-Tanner, S. (2015). Enhancing Career Management Preparedness and Mental Health. In Sustainable Working Lives (pp. 231-247). Springer Netherlands.

Sauermann, H., \& Stephan, P. (2013). Conflicting logics? A multidimensional view of industrial and academic science. Organization Science, 24(3), 889-909. 
De Vos, A., \& Dries, N. (2013). Applying a talent management lens to career management: The role of human capital composition and continuity. The International Journal of Human Resource Management, 24(9), 1816-1831.

Gangl, M. (2002). Changing labour markets and early career outcomes: labour market entry in Europe over the past decade. Work, Employment \& Society,16(1), 67-90.

Ferrie, J. E., Shipley, M. J., Newman, K., Stansfeld, S. A., \& Marmot, M. (2005). Selfreported job insecurity and health in the Whitehall II study: potential explanations of the relationship. Social science \& medicine, 60(7), 1593-1602.

Ahola, K., Toppinen-Tanner, S., Huuhtanen, P., Koskinen, A., \& Väänänen, A. (2009). Occupational burnout and chronic work disability: An eight-year cohort study on pensioning among Finnish forest industry workers. Journal of affective disorders, 115(1), 150-159.

Fritsch, M., \& Krabel, S. (2012). Ready to leave the ivory tower?: Academic scientists' appeal to work in the private sector. The Journal of Technology Transfer, 37(3), 271-296.

Taylor, A. R., \& Hooley, T. (2014). Evaluating the impact of career management skills module and internship programme within a university business school. British Journal of Guidance \& Counselling, 42(5), 487-499.

Farndale, E., Scullion, H., \& Sparrow, P. (2010). The role of the corporate HR function in global talent management. Journal of World Business, 45(2), 161-168.

Adcroft, A., \& Taylor, D. (2013). Support for new career academics: an integrated model for research intensive university business and management schools. Studies in Higher Education, 38(6), 827-840.

Pavitt, K. (1998). The social shaping of the national science base. Research policy, 27(8), 793-805.

Link, A. N., \& Siegel, D. S. (2007). Innovation, entrepreneurship, and technological change. Oxford University Press, USA.

Martinelli, D. (2001, September). Labour market entry and mobility of young French PhDs. In Innovative People-Mobility of skilled personnel in national innovation systems. OECD Proceedings (pp. 159-173).

Estabrooks, C. A., Derksen, L., Winther, C., Lavis, J. N., Scott, S. D., Wallin, L., \& Profetto-McGrath, J. (2008). The intellectual structure and substance of the knowledge utilization field: A longitudinal author co-citation analysis, 1945 to. Implementation Science, 3, 49.

Phipps, D., Jensen, K., \& Myers, J. G. (2012). Applying social sciences research for public benefit using knowledge mobilization and social media. InTech.

Klenk, N. L., \& Wyatt, S. (2015). The design and management of multi-stakeholder research networks to maximize knowledge mobilization and innovation opportunities in the forest sector. Forest Policy and Economics, 61, 77-86.

https://cariera.uvt.ro/, accessed on 20.06.15 